\title{
Comparison of Single-Step Methods to Enrich Lipase Concentrations in Bacterial Cell Lysates
}

\author{
Marie Kathleen Walsh ${ }^{1 *}$ \\ https://orcid.org/0000-0002-7323-5930 \\ Teif AbdulQani Najm ${ }^{1}$ \\ https://orcid.org/0000-0002-8040-1335 \\ ${ }^{1}$ Utah State University, Department of Nutrition, Dietetics and Food Sciences, Logan, Utah, USA. \\ Editor-in-Chief: Paulo Vitor Farago \\ Associate Editor: Acácio Zielinski
}

Received: 2020.07.27; Accepted: 2021.05.25.

${ }^{*}$ Correspondence: marie.walsh@usu.edu; Tel.: +1-435-797-2177 (M.K.W.)

HIGHLIGHTS

- Lipases were enriched from Geobacillus and Anoxybacillus lysates

- For each lipase, ethanol precipitation resulted in the highest enrichment fold

- Ethanol precipitation is a simple enrichment method that can result in high yields

\begin{abstract}
Lipases are currently used in food technology for the modification of fats and oils. The thermal stability of lipase is an essential characteristic for this application. This study compares four individual singlestep methods (heat treatment, ethanol precipitation, ammonium sulfate precipitation, and size-exclusion chromatography) to enrich lipase concentrations from thermophilic bacterial (Geobacillius stearothermophilus and Anoxybacillus flavithermus) cell lysates. SDS-PAGE and size exclusion chromatography were used to determine the molecular weights of the lipases and the enrichment efficiencies were determined using specific enzyme activities. The molecular weight of $\mathrm{G}$. stearothermophilus lipase was approximately $42 \mathrm{kDa}$, and approximately $33 \mathrm{kDa}$ for A. flavithermus lipase. For each organism, ethanol precipitation resulted in the highest enrichment fold, followed by ammonium sulfate precipitation, gel filtration and heat treatment respectively. The highest yields for $\mathrm{G}$. stearothermophilus lipase were obtained with ammonium sulfate precipitation, followed by get filtration, and ethanol precipitation respectively. The highest yields for $A$. flavithermus lipase were obtained from heat treatment followed by ammonium sulfate precipitation, gel filtration and ethanol precipitation respectively. Ethanol precipitation and heat treatment are simple methods for enzyme enrichment from cell lysates and can result in high enzyme yields with moderate enrichment folds compared to complex multi-step purification methods.
\end{abstract}

Keywords: thermophilic lipase, enzyme enrichment, zymography

\section{INTRODUCTION}

Enzymes are considered nature's catalysts. Currently, the fermentation of microorganisms is commonly used to produce enzymes [1]. Esterases (EC. 3.1.1.3, carboxylic ester hydrolases) and lipases (EC. 3.1.1.1, triacylglycerol hydrolases) are two major classes of hydrolytic enzymes of importance [2]. They hydrolyze the fatty acids in triacylglycerols in the presence of water. Additionally, they act as catalysts in interesterification 
and synthesis reactions [3]. Lipases can synthesize, hydrolyze, and rearrange fatty acids, thus, resulting in their extensive use in industrial applications [3].

Lipases play an important role because of their biocatalysts and biotechnological applications. Commercial lipases are used in the pharmaceutical, biodiesel and food science fields [4]. Furthermore, lipases are used in food technology for the modification of fats and oils to change triacylglycerol fatty acid composition by interesterification $[5,6]$. Most of these industrial enzymes are of microbial origin and are used in the modification or esterification of fats and oils to improve the overall health value, sensory and functional attributes of the oils [7].

Lipases are produced from several sources including plants, animals, and microorganisms (bacteria, yeast, and fungi) and can be isolated and purified for use in food processing. The high-catalytic activity, yield, and ease of purification makes the use of lipases very advantageous. Microbial lipases have been isolated from different sources including Thermomyces lanuginosa, Pseudomonas sp., Rhizopus oryzae, Asperigillus $s p$., Candida sp. and Bacillus sp. Lipases are characterized by the ability to complete reactions of both hydrolysis and synthesis, as well as working with different substrates such as alcohols, amines, and carboxylic acids [8]. In general, the thermal stability of the enzyme is an important characteristic that is desired by the food industry for interesterification of oils [9]. Because of this characteristic, the use of heat tolerant lipases can increase the reaction rate, stabilize the substrate, reduce microbial contamination, and improve the solubility of fat [10]. Thermophilic Geobacillus and Anoxybacillus are bacteria that can withstand high temperatures, ranging from $50-90^{\circ} \mathrm{C}$ and produce lipases that may have important industrial applications [9].

Lipase may be purified from crude extracts using a variety of techniques depending on the characteristics of the enzyme, such as molecular mass and isoelectric point. The purpose of this process is to increase the purity of the lipase and remove detrimental components including proteases [7]. Purification of enzymes has traditionally been achieved by several techniques such as precipitation, hydrophobic interaction chromatography, gel filtration, and ion exchange chromatography. Often a combination of these techniques are used. Here, we compared individual, single-step methods for the enrichment of lipases from $G$. stearothermophilus and $A$. flavithermus cell lysates.

Recently, lipases were purified from thermophilic bacteria but with several purification steps to get a $3 \%$ yield. The sequential steps including ammonium sulfate precipitation, Phenyl Sepharose CL4B, followed by Sephadex G-100 chromatography [11]. Also, a lipase was purified using a combination of heat treatment, DEAE-Cellulose, followed by Sephadex G-150 and G-25 to obtain a 19.7\% purification yield [12].

To date, there are few studies which have investigated the use of ethanol precipitation and heat treatment for the enrichment of lipases from thermophilic microbes. In addition, lipases have not been enriched using a single-step to get a $50 \%$ yield. In this study, we compared the efficiency of four different single-step methods, precipitation by ethanol, ammonium sulfate, heat treatment, or size-exclusion chromatography to enrich lipases from two different thermophilic bacteria (G. stearothermophilus and A. flavithermus). The enrichment yield and fold were determined for each method.

\section{MATERIAL AND METHODS}

Sephadex G-100, 4-nitrophenyl acetate, sodium dodecyl sulfate (SDS), tetramethyl ethylenediamine (TMED), acrylamide/bis-acrylamide 29:1, ammonium persulfate, glycine, Coomassie Brilliant Blue R-250, and bromophenol blue were purchased from Sigma-Aldrich (USA). Triton X-100, ammonium sulfate, and glycerol were obtained from Mallinckrodt Specialty Chemicals Co. (USA). Tris HCL and tris base were obtained from Fisher Scientific (USA). Protein concentration was determined using the BCA kit from Thermo Scientific (USA).

\section{Growth of microorganisms}

The culture of $G$. stearothermophilus was prepared by adding $0.1 \mathrm{ml}$ of stock solution obtained from NAMSA G. stearothermophilus spore suspension $\left(2.4 \times 10^{6}\right.$ spores $/ 0.1 \mathrm{ml}$, biological indicator for STEAM, LOT: S90601, Fisher Scientific, USA) to $10 \mathrm{ml}$ of sterile water. This diluted stock was incubated in water bath for $10 \mathrm{~min}$ at $80^{\circ} \mathrm{C}$. One $\mathrm{ml}$ of this was moved to $25 \mathrm{ml}$ of tryptic soy broth (TSB) media in a sterile 250 $\mathrm{ml}$ Erlenmeyer flask covered with sterile foil and incubated at $55^{\circ} \mathrm{C}$ for $24 \mathrm{~h}$ in a shaker at $100 \mathrm{rpm}$. The optical density (OD) of bacteria growth was measured using a spectrophotometer (BioSpec-1601, Shimadzu, USA) at $600 \mathrm{~nm}[13]$.

A. flavithermus TNO-09.006 culture was a gift from Remco Kort (Top Institute Food and Nutrition, The Netherlands) and grown using $0.1 \mathrm{ml}$ culture mixed with $25 \mathrm{ml} \mathrm{TSB}$ with $0.05 \mathrm{~g}$ potato starch in a sterile 250 
$\mathrm{ml}$ Erlenmeyer flask covered with sterile foil and incubated at $55^{\circ} \mathrm{C}$ for $14-18 \mathrm{~h}$ in a shaker at $100 \mathrm{rpm}$. Growth of $A$. flavithermus was confirmed by measuring OD 600 spectrophotometrically [14].

Frozen stocks were prepared by inoculating $2 \mathrm{ml}$ of an overnight culture to $20 \mathrm{ml}$ of a $30 \%$ glycerol solution (glycerol/TSB, w/v) and stored in $2.0 \mathrm{ml}$ cyro-vials at $-20^{\circ} \mathrm{C}$. Frozen stocks $(0.1 \mathrm{ml})$ of each organisms were added to $25 \mathrm{ml} \mathrm{TSB}$ in a sterile $250 \mathrm{ml}$ Erlenmeyer flasks covered with sterile foil and incubated at $55^{\circ} \mathrm{C}$ for $16-18 \mathrm{~h}$ in a shaker at $100 \mathrm{rpm}$ [13]. The $25 \mathrm{ml}$ growth of bacteria was added to $1 \mathrm{~L}$ of TSB and cells were grown at $55^{\circ} \mathrm{C}$ at $100 \mathrm{rpm}$ until the $\mathrm{OD}$ at $600 \mathrm{~nm}$ was between 0.7 to 0.9 . The bacteria were separated from the medium by centrifuging at $3000 \mathrm{rpm}$ for $10 \mathrm{~min}$ at $10^{\circ} \mathrm{C}$. The cells were washed in $10 \mathrm{ml} \mathrm{Tris-HCL}$ buffer and centrifuged again as described above. After centrifugation, the cells were mixed with 5-10 ml Tris buffer (50 mM Tris HCL, pH 7.5), and this mixture was sonicated at $40 \%$ amplitude in an ice bath (Qsonica, LLC, Newtown, CT) for $1 \mathrm{~min}$ using a $4.5 \mathrm{~mm}$ microtip and a Qsonica Sonicator power source. The sonicated solution was centrifuged at $10,000 \mathrm{rpm}$ at $0^{\circ} \mathrm{C}$ for $20 \mathrm{~min}$ and the lysate was filtered using a microfilter 1.0 $\mu \mathrm{m}$ (Glassfiber Prefilter, Tullagreen, Carrigtwohill Co. Ireland). The crude protein lysates were used for further experiments.

\section{Total protein and enzyme activity}

Lipases were assayed using the substrate 4-nitrophenyl acetate (Sigma-Aldrich, USA). Five ml of substrate stock solutions were prepared using an acetonitrile and isopropanol mixture $(1: 4 \mathrm{v} / \mathrm{v})$ as previously described [15]. One $\mathrm{ml}$ of the stock was diluted with $20 \mathrm{ml}$ of substrate buffer $(50 \mathrm{mM}$ Tris HCL, $\mathrm{pH} 7.5$ containing $1 \mathrm{mM} \mathrm{CaCl}_{2}$ and $0.3 \%$ Triton X100). Samples were added to substrate buffer and the absorbance at $410 \mathrm{~nm}$ was recorded every 5 seconds over $1 \mathrm{~min}$ using spectrophotometer at $22^{\circ} \mathrm{C}$. One unit of lipase activity was defined as $1 \mu \mathrm{mol}$ substrate hydrolyzed per minute under the assay conditions. This is referred to as the standard lipase assay. Specific activity was determined by calculating the ratio of the lipase activity $(U)$ and protein concentration $(\mathrm{mg})$ and expressed as $U / \mathrm{mg}$. The protein content was determined using protein determination kit (Pierce Chemical Co., USA).

\section{Gel electrophoresis}

SDS-PAGE was carried out using a $5 \%$ stacking gel and a $12 \%$ running gel under reducing conditions as previously described [16]. Samples containing $20 \mu \mathrm{g}$ of protein in $20 \mu \mathrm{l}$ buffer were mixed with $10 \mu \mathrm{l}$ of SDS sample buffer $(3 \mathrm{X}=1 \mathrm{M}$ Tris $\mathrm{HCL} \mathrm{pH} 6.8,10 \%$ SDS, $0.3 \%$ Bromophenol blue, $1 \% \beta$-mercaptoethanol, and $30 \%$ glycerol) and heated at $90^{\circ} \mathrm{C}$ for $5 \mathrm{~min}$. Running buffer, $0.1 \%$ (w/v) SDS dissolved in $25 \mathrm{mM}$ Tris and $192 \mathrm{mM}$ glycine $\mathrm{pH} 8.3$, was used at $60 \mathrm{~V}$ for the first $15 \mathrm{~min}$ and $100 \mathrm{~V}$ for an additional 90 min using a Mini-Protean Tetra Cell (Bio-Rad Laboratories, USA). Gels were stained using $0.1 \%(\mathrm{w} / \mathrm{v})$ Coomassie Brilliant Blue R-250, 45\% (v/v) methanol and 10\% (v/v) acetic acid for $20 \mathrm{~min}$. A low molecular range protein standard was used as molecular weight markers ( $\beta$-galactosidase $120 \mathrm{kDa}$, bovine serum albumin $90 \mathrm{kDa}$, ovalbumin $50 \mathrm{kDa}$, carbonic anhydrase $34 \mathrm{kDa}$, $\beta$-lactoglobulin $26 \mathrm{kDa}$, and lysozyme $20 \mathrm{kDa}$ ) (Thermo Scientific Prestained Protein Molecular Weight Marker \# 26612) [16]. The migration distances of the standards was graphed vs the log molecular weight of the standards. The migration distances of the putative lipase bands was determined and the molecular weights were calculated.

In this study, zymography was used in conjunction with SDS-PAGE under reducing conditions with both chromogenic zymography and transfer zymography. For chromogenic zymography, after electrophoresis, the SDS gel was washed for $10 \mathrm{~min}$ in 2.5\% (v/v) Triton X-100 (50 mM Tris HCL pH 8) and other 10 min with $1 \%$ $(\mathrm{v} / \mathrm{v})$ Triton X-100 in the same Tris buffer. The gel was washed with $20 \%$ isopropanol for $20 \mathrm{~min}$ [17]. Then washed with distilled water three times and the gel was incubated with an activation buffer $(50 \mathrm{mM}$ Tris- $\mathrm{HCL}$ $\mathrm{pH} 8.0$ ) for $30 \mathrm{~min}$ at room temperature. The washing steps were used to remove denaturating agents to refold the lipases. The gel was then placed in the chromogenic substrate solution $(0.01 \% \mathrm{w} / \mathrm{v})$ phenol red, 10 $\mathrm{mM} \mathrm{CaCl}_{2}$ with lipidic substrate $(0.5 \%(\mathrm{v} / \mathrm{v})$ glyceryl tributyrate (Sigma-Aldrich, USA) and $0.5 \%(\mathrm{v} / \mathrm{v})$ olive oil, then incubated at 45 to $55^{\circ} \mathrm{C}$. A yellow band observed in the gel was indicative of lipase activity [18].

After electrophoresis, the denaturing agents were removed from gel using same solutions as described above in the chromogenic zymography for transfer zymography. The substrate gel was prepared as described in Table 1. A sandwich blot was assembled and included filter paper, SDS gel, substrate gel, filter paper and was loaded into Bio-Rad Mini Trans-Blot electrophoretic transfer cell unit. Running buffer without SDS was used (25 mM Tris and $192 \mathrm{mM}$ glycine $\mathrm{pH}$ 8.3) and the transfer voltage was $15 \mathrm{~V}$ for $25 \mathrm{~min}$ at $4{ }^{\circ} \mathrm{C}$ [19]. The gel was removed and incubated with activation buffer $(50 \mathrm{mM}$ Tris HCL, $25 \mathrm{mM}$ sodium chloride, $\mathrm{pH} 8.9$ ) at $55^{\circ} \mathrm{C}$ for $24 \mathrm{~h}$. Lipase activity was observed as white bands under a grayish background [19, 20]. 
Table 1. Substrate gel for transfer zymography

\begin{tabular}{lcc}
\hline Component & Volume $(\mathbf{m L})$ & Final concentration $(\%)$ \\
\hline 40\% Acrylamide/Bis-acrylamide $(29: 1 \%)$ ratio & 2.4 & 40 \\
Glycerol Tributyrate & 0.72 & 12 \\
Olive oil & 0.147 & 2.5 \\
Distilled Water & 2.67 & 44.5 \\
Sonication one minutes (5 pulse at 20\% amplitude) & & \\
Ammonium persulfate (10\% w/v) & 0.06 & 1 \\
TEMED & 0.003 & 0.05 \\
\hline
\end{tabular}

\section{Enrichment of lipases from cell lysates}

Lipases from G. stearothermophilus and A. flavithermus extracts were enriched in cell lysates using four single-step methods including heat treatment, ethanol precipitation, ammonium sulfate precipitation, and size-exclusion chromatography. For each method, protein content and enzyme activity were measured using the standard lipase assay and protein determination kit and protein profiles were determined by SDS-PAGE analysis. Initially, cells from a $25 \mathrm{~mL}$ overnight growth were used for each method, then when the optimal conditions were determined, cells from $2 \mathrm{~L}$ of an overnight growth were used to determine the enrichment fold and yield. All experiments were replicated 3 times and all assays were conducted in triplicate and standard deviations (SD) were calculated.

The cell lysates from $G$. stearothermophilus and $A$. flavithermus after heating at $\left(50-80^{\circ} \mathrm{C}\right)$ for 10 min in a water bath was done and the temperature was monitored every $25 \mathrm{sec}$ to ensure the required temperature was maintained using a precision digital thermometer. Samples were placed in an ice bath after heat treatments to reduce the temperatures. The solutions were centrifuged at $10,000 \times \mathrm{g}$ for $30 \mathrm{~min}$ at $4^{\circ} \mathrm{C}$ to precipitate denatured proteins [21] and the supernatants were saved. The supernatants were assayed for lipase activity and protein content using the standard lipase assay and protein determination kit described above.

The cell lysates were mixed with various concentrations of ethanol (20-80\%). One ml of lysate was diluted with 0 to $7 \mathrm{ml}$ with deionized water before cooling to $0^{\circ} \mathrm{C}$ in an ice bath. Ethanol (2 to $9 \mathrm{ml}$ ) was gradually added to the lysates to get final ethanol concentrations ranging from $20-80 \%$ at $4^{\circ} \mathrm{C}$ [16]. Samples were centrifuged at $8,000 \times \mathrm{g}$ at $4^{\circ} \mathrm{C}$ for $20 \mathrm{~min}$ and the precipitate (pellet) was washed in $50 \mathrm{mM}$ Tris HCL buffer, $\mathrm{pH} 7.5$, centrifuged again with the same conditions, then solubilized in $1.0 \mathrm{~mL}$ of the Tris buffer. The solubilized pellets were assayed for lipase activity and protein content using the standard lipase assay and protein determination kit described above.

Ammonium sulfate protein precipitation was conducted as described by a previous method with some modifications [11]. Different concentrations of ammonium sulfate $(0,20 \%, 40 \%, 60 \%, 80 \%$, and $95 \%$ ) were added to cell lysates at $4^{\circ} \mathrm{C}$ with stirring. Each pellet, after centrifugation at $10,000 \mathrm{x} \mathrm{g}$ for 30 min at $4^{\circ} \mathrm{C}$, was collected and dissolved in $50 \mathrm{mM} \mathrm{pH} 7.5$ Tris $\mathrm{HCL}$ buffer at $4^{\circ} \mathrm{C}$. The solutions were dialyzed using dialysis cassettes (Slide-A- Lyzer 10,000 MWCO, Thermo Scientific, USA) for $24 \mathrm{~h}$ at $4^{\circ} \mathrm{C}$ with fresh dialysis buffer replacing the buffer every $4 \mathrm{~h}$. After dialysis, samples were assayed for lipase activity and protein content using the standard lipase assay and protein determination kit described above.

The cell lysates were loaded onto a Sephadex G-100 column $(36.0 \mathrm{~cm} \times 2 \mathrm{~cm})$ equilibrated with $50 \mathrm{mM}$ Tris buffer, $\mathrm{pH}$ 7.5. Proteins were then eluted with the same buffer with a flow rate of $0.5 \mathrm{~mL} / \mathrm{min}$. Protein fractions were collected using an ISCO Model 1200 (Teledyne ISCO, USA) fraction collector. The fractions were assayed for lipase activity and protein content using the standard lipase assay and protein determination kit described above. Additionally, protein standards (bovine serum albumin or BSA at $67 \mathrm{kDa})$, pepsin (34.5 $\mathrm{kDa})$, trypsin $(23.3 \mathrm{kDa})$, lysozyme $(14.3 \mathrm{kDa})$ and blue dextran were run through the column and their elution volumes recoded. The elution volumes of the standards vs the molecular weights were plotted and the elution volumes of the lipase activity peaks were used to calculate the estimated molecular weights.

\section{RESULTS}

\section{Identification of lipases in cell lysates}

Thermophilic bacteria grow at high temperature range of $45-70{ }^{\circ} \mathrm{C}$ [22] and produce thermophilic enzymes. Lipases from two different thermophilic bacteria, G. stearothermophilus and $A$. flavithermus, were enriched in cell lysates using 4 different single-step methods. The total lipase activity and total protein in the cell lysates from $G$. stearothermophilus were $4761 \mathrm{U}$ and $117.6 \mathrm{mg}$ with a specific activity of $40.5 \mathrm{U} / \mathrm{mg}$ using 
4-nitrophenyl acetate as the substrate (Table 2). Cell lysates from $A$ flavithermus showed a total activity of $803 \mathrm{U}$, and the total protein was $110.1 \mathrm{mg}$ with a specific activity of $7.3 \mathrm{U} / \mathrm{mg}$ using the same substrate (Table 2). Overall, the results show that lysates from G. stearothermophilus have a specific activity that is 5.5 times higher than the activity of lysates from $A$. flavithermus. There was a slight difference in the total protein content of lysates from each organism.

Table 2. Enrichment efficiency of lipases from thermophilic bacteria within each single-step method

\begin{tabular}{llccccc}
\hline Source & Method & $\begin{array}{c}\text { Total Activity } \\
\text { (U) }\end{array}$ & $\begin{array}{c}\text { Total protein } \\
\text { (mg) }\end{array}$ & $\begin{array}{c}\text { Specific } \\
\text { activity } \\
\text { (U/mg) }\end{array}$ & $\begin{array}{c}\text { Enrichment } \\
\text { (fold) }\end{array}$ & $\begin{array}{c}\text { Yield } \\
\text { (\%) }\end{array}$ \\
\hline Geobacillus & crude & $4761 \pm 58$ & $117.6 \pm 1$ & $40.5 \pm 0.6$ & 1 & 100 \\
stearothermophilus & Heat $\left(70^{\circ} \mathrm{C}\right)$ & $2572 \pm 4$ & $56.0 \pm 0.4$ & $46.0 \pm 0.4$ & 1.1 & 54 \\
& Ethanol & $2411 \pm 120$ & $37.8 \pm 0.4$ & $63.8 \pm 3$ & 1.5 & 50 \\
& $(80 \%)$ & & & & & \\
& Amm (95\%) & $3918 \pm 148$ & $73.9 \pm 0.9$ & $53.0 \pm 2$ & 1.3 & 82 \\
& Gel filtration & $3430 \pm 251$ & $62.6 \pm 2$ & $54.8 \pm 7$ & 1.3 & 72 \\
\hline Anoxybacillus & crude & $803 \pm 28$ & $110.1 \pm 6$ & $7.3 \pm 0.1$ & 1 & 100 \\
flavithermus & Heat (55 $(5)$ & $730 \pm 23$ & $95.3 \pm 2$ & $7.6 \pm 0.1$ & 1 & 91 \\
& Ethanol & $430 \pm 3.0$ & $10.0 \pm 0.1$ & $43.0 \pm 0.2$ & 5.9 & 53 \\
& (60\%) & & & & & \\
& Amm (80\%) & $680 \pm 13.2$ & $65.0 \pm 0.9$ & $10.4 \pm 2.0$ & 1.4 & 84 \\
& Gel filtration & $538 \pm 34.8$ & $42.6 \pm 1.2$ & $12.6 \pm 1.4$ & 1.7 & 67 \\
\hline
\end{tabular}

In comparison to previous findings, the total lipase activity of lysates from G. stearothermophilus (4761 U) was higher than that of Geobacillus sp strain ARM and [23], Geobacillus stearothermophilus AH22, [12]. Also, the specific activity was higher than that of Geobacillus stearothermophilus PS 11 [24]. The total activity and specific activity of lysates from Anoxybacillus flavithermus was $803 \mathrm{U}$ and $7.3 \mathrm{U} / \mathrm{mg}$; which is lower than the lipase activity reported from Anoxybacillus flavithermus HBB 134 [11].

SDS-PAGE was used to analyze the cell lysates from the thermophilic bacteria after denaturation under reducing conditions to estimate the molecular weights of the lipases. Figure $1 \mathrm{~A}$ shows the protein profile of lysates from G. stearothermophilus; the arrow indicates the putative lipase band with the molecular weight of approximately $42 \mathrm{kDa}$. Figure $2 \mathrm{~A}$ shows the protein profile of lysates from $A$. flavithermus; the arrow indicates the putative lipase band with the molecular weight of approximately $33 \mathrm{kDa}$.

Activity staining is a method used to verify the bands and molecular weights of enzymes. Activity staining was performed using a substrate (glyceryl tributyrate and olive oil) gel electrophoresis with lysates from thermophilic bacteria. There are two different techniques used to indicated lipase activity, chromogenic and transfer zymography. For both methods, the proteins were reactivated by washing the SDS-PAGE gel with activation buffer to remove SDS and the gel was incubated at $55^{\circ} \mathrm{C}$ for $1-2 \mathrm{~h}$ in TrisHCL buffer pH 8.0 to renature the lipases. This research used both zymography techniques to confirm the molecular weights.

In chromogenic zymography, an active lipase will reduce the $\mathrm{pH}$ of the gel, which changes the phenol red color to yellow [18]. Figures $1 \mathrm{~B}$ and $2 \mathrm{~B}$ show a yellow band since the lipase changed the color in the gel from red to yellow corresponding to a lipase band. The lipase band in lysates from G. stearothermophilus have a molecular weight of approximately $42 \mathrm{kDa}$ (Figure 1B) and that from $A$. flavithermus has an approximate molecular weight of $33 \mathrm{kDa}$ (Figure $2 \mathrm{~B}$ ) indicated by the arrows.

Transfer zymography was also used to determine the molecular weights of the lipase bands. The lipase band was transferred from the SDS-PAGE gel to the substrate gel using electroblotting. The substrate gel was then incubated with activation buffer and a color change indicates the presence of an active lipase [17]. Figures $1 \mathrm{C}$ and $2 \mathrm{C}$ show zones of lipase activity on the white or cloudy background of lysates from $G$. stearothermophilus with molecular weight of approximately $42 \mathrm{kDa}$ (Figure $1 \mathrm{C}$ ) and $A$. flavithermus with molecular weight of approximately $33 \mathrm{kDa}$ (Figure $2 \mathrm{C}$ ). As shown in Figure 1C, the lipase band was clearly visible for $G$. stearothermophilus because a higher lipase activity was observed after incubating the gel with reaction buffer. Whereas, the contrast between the band and the background was less visible for lipase isolates from $A$. flavithermus because the lipase activity was lower, perhaps because the lipase did not renature as well as the lipase from $G$. stearothermophilus (Figure $2 \mathrm{C}$ ).

The molecular weight of enzymes obtained were different for each microbe which agrees with previous reports that show that the molecular weight of lipases are different and are dependent on the source. For example, the molecular weight of a lipase from Bacillus gladioli ATCC10248 was $43 \mathrm{kDa}$ [25], Bacillus 
thermoleovorans CCRII was $11 \mathrm{kDa}$ [26], Bacillus subtilis NRRL B8079 was 54 kDa [27], and Bacillus acidocaldarius ORF3 was $34 \mathrm{kDa}$ [27]. Specifically, for the Geobacillus and Anoxybacillus genus, the molecular weight of lipase from Geobacillus sp. SBS-4S was 43.4 kDa [28] Geobacillus stearothermophilus JC was $44.3 \mathrm{kDa}$ [29], Anoxybacillus sp. PDF1 was $26 \mathrm{kDa}$ [30], and Anoxybacillus flavithermus DSM was $24.36 \mathrm{kDa}[31]$.

\section{Enrichment of lipases from cell lysates}

In this study, we compared the efficiency of four different single-step methods including heat treatment, ethanol precipitation, ammonium sulfate precipitation, and size-exclusion chromatography (Sephadex G-100) to enrich lipases from the thermophilic bacterial lysates. Enrichment fold and yield from the four methods were used to compare the results of each method. A high yield with a high enrichment fold indicates a greater concentration of the protein of interest with removal of contaminants including other proteins present in the crude cell lysates.

Enrichment by heat treatment results in precipitating proteins via centrifugation which aggregate during the heat treatment. The thermotolerance of some proteins will keep them in solution while less heat tolerant proteins will aggregate and precipitate with centrifugation. In this study, different temperatures were used to treat crude cell lysates. The activity of lysates from $\mathrm{G}$. stearothermophilus remained high until $75^{\circ} \mathrm{C}$, while the lowest enzyme activity was at $80^{\circ} \mathrm{C}$ (Figure $3 \mathrm{~A}$ ). Comparing the soluble protein with the lipase activity, we selected $70^{\circ} \mathrm{C}$ to use for the heat treatment since it showed both high soluble protein and high lipase activity. The lipase activity from $A$. flavithermus was active when treated at 50 to $80^{\circ} \mathrm{C}$; the enzyme activity was highest at $55^{\circ} \mathrm{C}$ and also showed high soluble protein at that temperature (Figure $3 \mathrm{~B}$ ), therefore, $55^{\circ} \mathrm{C}$ was used for the heat treatment method.

Figure 4, lanes 4A2 and 4B2 show the supernatants of lysates from each organism treated at 70 and $55^{\circ} \mathrm{C}$. Heat treatment of cell lysates from G. stearothermophilus (seen in Figure 4A, lane 2) can be compared with the untreated crude lysate (lane 1). The number of protein bands at $70^{\circ} \mathrm{C}$ were less than seen in the lysates. This indicated that heat treatment at $70^{\circ} \mathrm{C}$ precipitated proteins which are not thermostable and increases the enrichment fold. The protein bands from the untreated lysate and the heat treated lysate at $70^{\circ} \mathrm{C}$ include a band with the molecular weight of $42 \mathrm{kDa}$. Additionally, the lysate and heat treated lysate using $55^{\circ} \mathrm{C}$ for $A$. flavithermus showed a band with a molecular weight of approximately $33 \mathrm{kDa}$ (Figure 4B lane 2).

The enzymatic yield and enrichment fold after heat treatment at $70^{\circ} \mathrm{C}$ for $\mathrm{G}$. stearothermophilus was $54 \%$ and 1.1 -fold respectively while that from $A$. flavithermus was $91 \%$ and 1 fold at $55^{\circ} \mathrm{C}$ (Table 2). The specific activity of lysates from $G$. stearothermophilus after treat at $70^{\circ} \mathrm{C}$ was $46 \mathrm{U} / \mathrm{mg}$ which was 6 time higher than the specific activity from $A$. flavithermus after treatment at $55^{\circ} \mathrm{C}(7.6 \mathrm{U} / \mathrm{mg})$. The total protein in $G$. stearothermophilus lysates was reduced by almost half, while there was little reduction in the total protein of A. flavithermus lysates. For $G$. stearothermophilus this result refers to removal of $46 \%$ of proteins from the lysates using one single enrichment step and an increase in lipase specific activity to 1.1 (Table 2). Ekinci et al. [12] reported an $85 \%$ yield and 1.3-fold purification of a lipase from G. stearothermophilus AH22 using $70^{\circ} \mathrm{C}$. Also, heat treatment was used to purify a lipase from Staphylococcus aureus, and the yield was $74.6 \%$, and the purification fold was 1.57 -fold using $55^{\circ} \mathrm{C}$ [32].

The enrichment of lipases from thermophilic bacteria lysates was evaluate using ethanol precipitation. Ethanol precipitation is a technique used to reduce the protein content through precipitate of protein and miscibility with water. This precipitation technique is an easier method compared to ammonium sulfate precipitation because the precipitate does not need an additional dialysis step to remove residual salts [16]. Temperature control is essential with this method to avoid protein denaturation so the temperature must be held at below $10^{\circ} \mathrm{C}$.

To determine the best ratio of ethanol concentration for precipitating lipases, different concentrations of ethanol $(20-80 \%(v / v))$ were used. The lipase activity from $G$. stearothermophilus (pellet) increased with an increase in ethanol up to $80 \%$ ethanol. The protein content of the pellets was also the lowest at $80 \%$ ethanol (Figure 5A). With $20-70 \%$ ethanol, the lipase partially precipitated, and the enzyme activity was approximately $35-40 \%$ less than at $80 \%$ ethanol. Protein patterns of the $80 \%$ ethanol precipitate is shown in the SDS-PAGE (Figure 4A lane 3 ) and a band at $42 \mathrm{kDa}$ is observed.

Ethanol precipitation of lysate from $A$. flavithermus is shown in Figure $5 \mathrm{~B}$. The highest lipase activity was observed at $60 \%$ ethanol with a low protein concentration. With increased ethanol concentration to $80 \%$, the lipase activity in the pellet decreased by approximately 50\%, which indicates that the concentration of ethanol over $60 \%$ precipitated the lipase. The protein patterns of lysates and ethanol precipitated protein at $60 \%(\mathrm{v} / \mathrm{v})$ 
is shown in the SDS-PAGE and the protein band with molecular weight of $33 \mathrm{kDa}$ is observed (Figure 4B lane 3).

Regarding the lipase enrichment by ethanol precipitation, the yield of lipase in the pellet from $G$. stearothermophilus was 50\%, and enrichment fold was 1.5-fold (Table 2). Lipase from ethanol precipitation of $A$. flavithermus lysate showed a $53 \%$ yield with a 5.9 enrichment fold (Table 2). As a result, ethanol precipitation enriched the lipases with the highest specific activity and enrichment fold compared to other methods for both organisms. In this study, activity yield for thermophilic bacteria was lower than that from Candida cylindracea which was $84 \%$ and Penicillium camembertii Thom PG-3 which was $85.8 \%$ using $80 \%$ ethanol [33].

Protein precipitate by ammonium sulfate is a classical technique used for the purification of proteins; it is depended on the protein concentration as well as the temperature, $\mathrm{pH}$, and isoelectric point of proteins. Ammonium sulfate, with its low cost and availability, makes it an accessible method for protein enrichment. This study used gradual graded ratios of ammonium sulfate $(20-95 \%)$ to precipitate protein in the lysates of both organisms while keeping the temperature of the solution below $10.0^{\circ} \mathrm{C}$.

For both organisms, an increase in ammonium sulfate resulted in higher specific activities (Figure 6A and B). Ammonium sulfate precipitation (Figure 6A) from $G$. stearothermophilus lysates increased in specific activity and was the highest at $95 \%$ ammonium sulfate. At this concentration of ammonium sulfate, the lowest protein concentration was also observed in both $6 \mathrm{~A}$ and $6 \mathrm{~B}$. For lysates from $A$. flavithermus the highest specific activity was observed at $80 \%$ ammonium sulfate which also had a low protein concentration. Protein patterns of ammonium sulfate precipitation at $95 \%$ (pellet) with lysates from G. stearothermophilus are shown in SDS-PAGE (Figure 4A, lane 4). A major protein band with a molecular weight $42 \mathrm{kDa}$ was predominant in the gel. The protein patterns $A$. flavithermus at $80 \%$ ammonium sulfate are shown in the SDS-PAGE (Figure $4 \mathrm{~B}$ lane 4) and with a band at $33 \mathrm{kDa}$ is visible.

From these results, the yield of lipase from $G$. stearothermophilus lysates at $95 \%$ ammonium sulfate was $82 \%$ with a 1.3 enrichment fold, for $A$. flavithermus there was an $84 \%$ yield with a 1.4 enrichment fold (Table 2). Ammonium sulfate precipitation did increase the enrichment fold of lipases from both organisms. The enrichment yield of the lipase from $G$. stearothermophilus was similar to that from $G$. stearothermophilus AH22 lysates which had an $85 \%$ yield with a 1.3 fold purification [12]. In this study, the enrichment fold of lipase from $A$. flavithermus was approximately higher (1.4-fold) than lipase from $A$. flavithermus HBB 134 (1.2-fold), and the yield was similar when using an ammonium sulfate concentration between 20 and $60 \%$ [11].

Purification of lipases has involved the use of classic chromatographic techniques including ion exchange, gel filtration or affinity chromatography, which usually result in high purification folds. Lipases from thermophilic bacteria were enriched by size-exclusion chromatography (Figure 7A and 7B). All the fractions were assayed for protein concentration and lipase activity. The lipase activity of fractions 20-40 for $G$. stearothermophilus was high with a corresponding high protein concentration. The lipase activity of fractions 60-80 from $A$. flavithermus showed high lipase activity with a relatively low protein concentration. Fractions from the Sephadex G-100 column with lipase activity were pooled and were analyzed by SDS-PAGE (Figure 4A and $4 \mathrm{~B}$ lanes 5). As expected, the $G$. stearothermophilus peak contained the targeted protein with a molecular weight of $42 \mathrm{kDa}$, while $A$. flavithermus peak had enriched lipase band with molecular weight of 33 $\mathrm{kDa}$. Additionally, molecular weight protein standards were used to calibrate the column (BSA, pepsin, trypsin, and lysozyme) and their elution times are superimposed on the chromatograms in Figure 7. Based on the elution times of the standards, the molecular weights of the lipases from G. stearothermophilus and A. flavithermus were calculated to be 42 and $33 \mathrm{kDa}$, which corroborates with the molecular weight determinations from SDS-PAGE.

The specific activity of lipase from G. stearothermophilus in pooled fractions was $54.8 \mathrm{U} / \mathrm{mg}$, which is higher than the lysate $(40.5 \mathrm{U} / \mathrm{mg})$ and the total protein decreased approximately $53 \%$ from the total protein in the lysate (Table 2). The yield was $72 \%$ and the enrichment fold was 1.3 . The specific activity of the lipase in pooled fractions from $A$. flavithermus was $12.6 \mathrm{U} / \mathrm{mg}$ with a $67 \%$ yield and 1.7 enrichment fold (Table 2). This method resulted in a high a enrichment fold for $A$. flavithermus. In previous research, the yield of lipase purified from Microbacterium sp. was $20.8 \%$ and 2.1 fold using Sephadex G-100 [46]. Also, two different Sephadex resin were used to purify a lipase from $G$. stearothermophilus AH 22; the purification yield was $34.7 \%$ with Sephadex G-150 while the yield for a second loading was 19.7\% using Sephadex G-25 [12]. While purification yield and purification fold of lipase isolated from $A$ flavithermus HBB 134 were $3 \%$ and 7.4 fold using a Sephadex G-100 column [11]. 
The enrichment efficiency of lipases from $G$. stearothermophilus and $A$. flavithermus with the different single-step methods is summarized in Table 2. Ethanol showed the highest enrichment folds for lipases from both organisms with similar enrichment yields. The enrichment folds using ammonium sulfate were similar for each organism and the enrichment fold using chromatography was higher for the lipase from $A$. flavithermus than from $G$. stearothermophilus. In comparison between both thermophilic sources, ethanol precipitation was the most efficient method with high enrichment folds and yields. Ammonium sulfate and gel filtration techniques showed high lipase yield from both thermophilic bacteria. With each enrichment method, we did not achieve 100\% lipase purification and we believe that the putative lipase bands shown in Figure 4 may not be solely lipase proteins. The purpose of this research was to find a simple, single-step method that resulted in an increase in the enrichment fold while maintaining a high enzyme yields.

\section{CONCLUSIONS}

Depending on the application of the thermophilic lipase, a method should be selected based on purification need vs. method complexity. The commercial use of lipases in the food industry does not always require high purity [12] while other uses, such as pharmaceutical, do require high purity. Our study enables researchers to choose the desired level of lipase purity, thereby reducing the complexity of the purification process. In our study, lipases were enriched using single-step methods (heat treatment, ethanol precipitation, ammonium sulfate precipitation, and gel filtration chromatography) in cell lysates. Lipases were enriched from two different thermophilic bacteria (G. stearothermophilus and A. flavithermus) and each method was evaluated for enrichment efficiency by measuring specific enzyme activities. Among the methods, the lipases from $G$. stearothermophilus and A. flavithermus enriched by ethanol precipitation had yields of $50 \%$ to $53 \%$ and enrichments of 1.5-fold and 5.6-fold respectively. Lipases are currently used in food technology; lipase can hydrolyze and esterify fatty acids, thus, resulting in their extensive use in industrial applications.

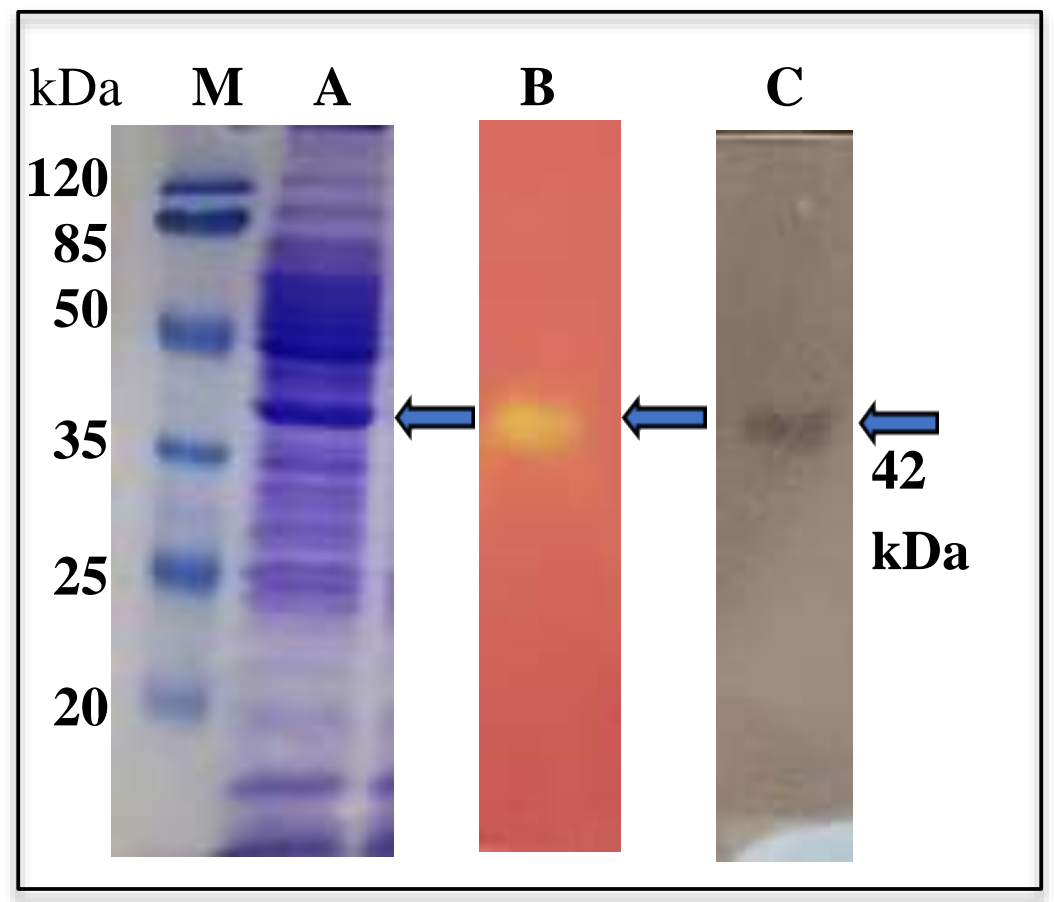

Figure 1. SDS-PAGE analysis of crude cell lysates from Geobacillus stearothermophillus. A. SDS-PAGE gel stained with Coomassie blue along with molecular weight markers (M). B. Chromogenic zymography activated with phenol red, glycerol tributyrate and olive oil as substrates. C. Transfer zymography activated with glycerol tributyrate and olive oil as substrates. 


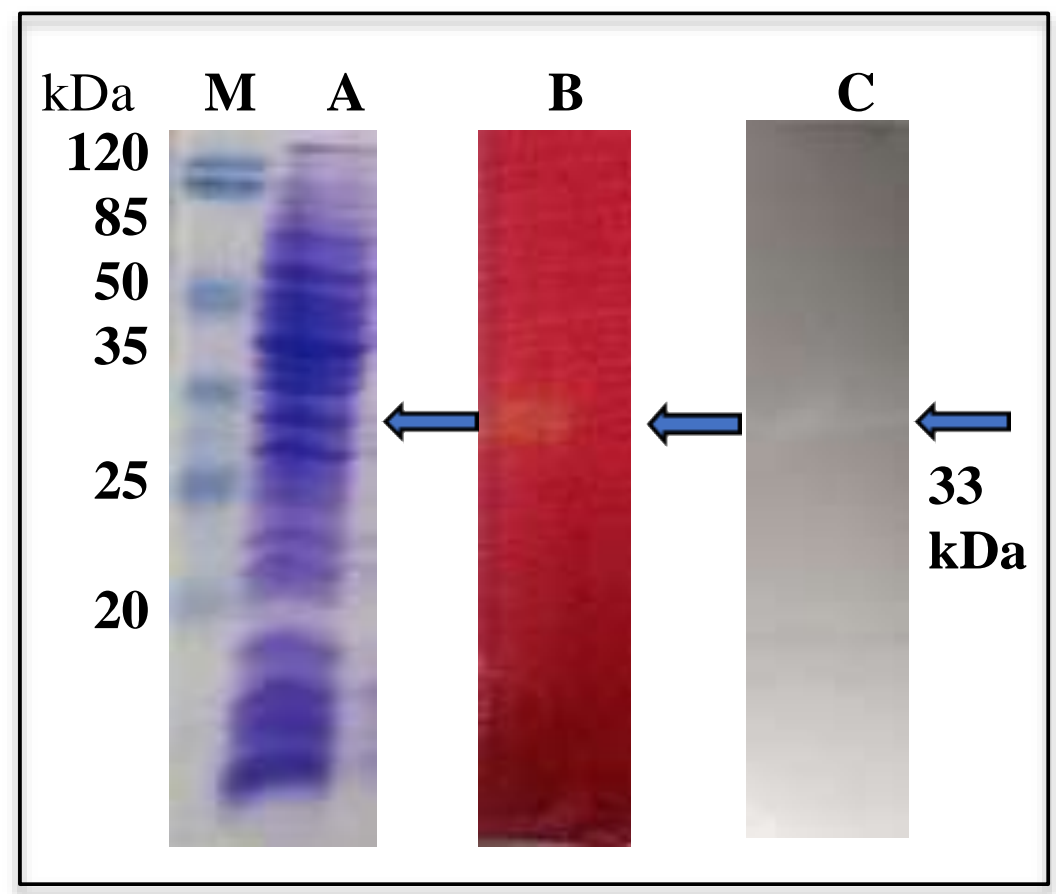

Figure 2. SDS-PAGE analysis of crude cell lysates from Anoxybacillus flavithermus. A. SDS-PAGE gel stained with Coomassie blue along with molecular weight markers (M). B. Chromogenic zymography activated with phenol red glycerol, tributyrate and olive oil as substrates. C. Transfer zymography activated with glycerol tributyrate and olive oil as substrates.

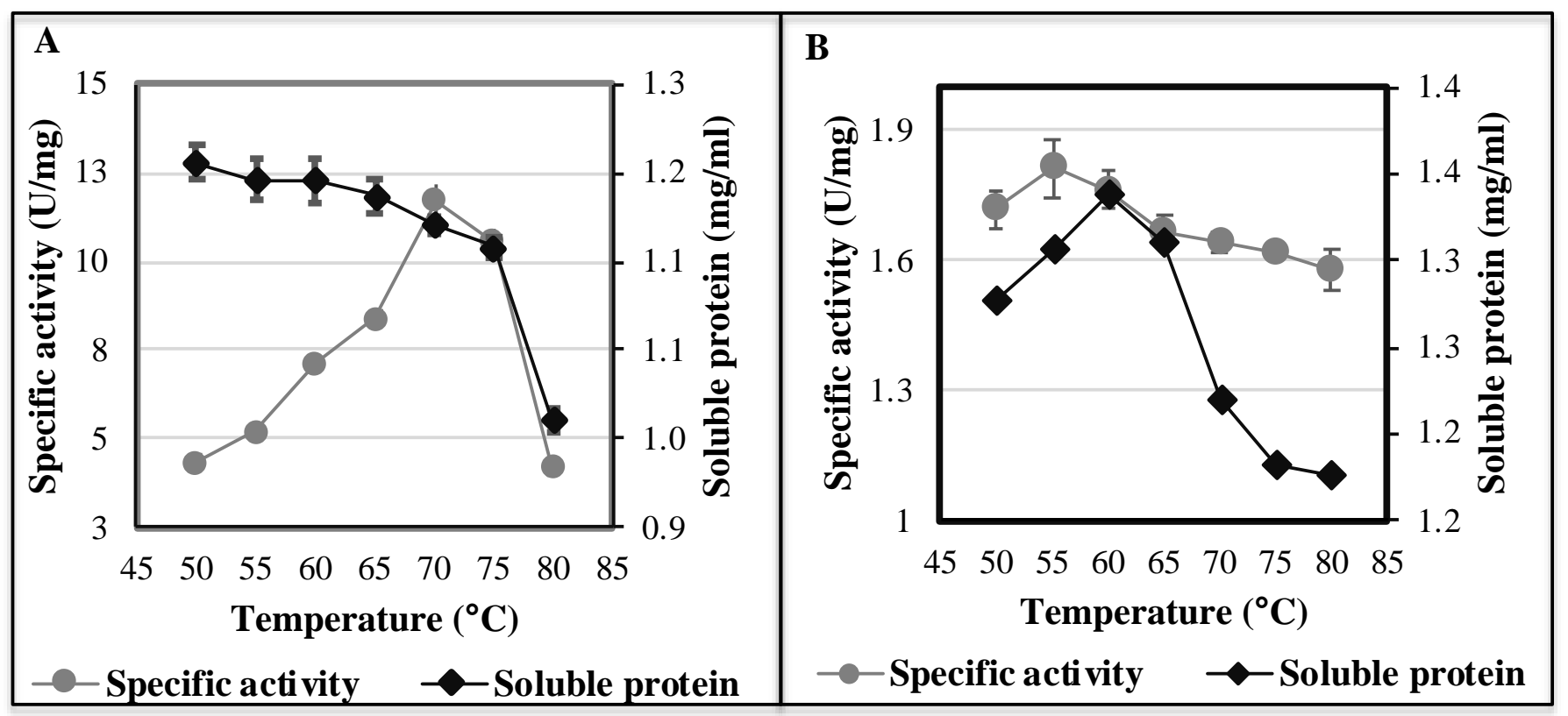

Figure 3. Lipase activity and soluble protein from cell lysates of Geobacillus stearothermophilus (A) and Anoxybacillus flavithermus (B) in supernatants after heat treatment. Error bars represent the standard deviation. 


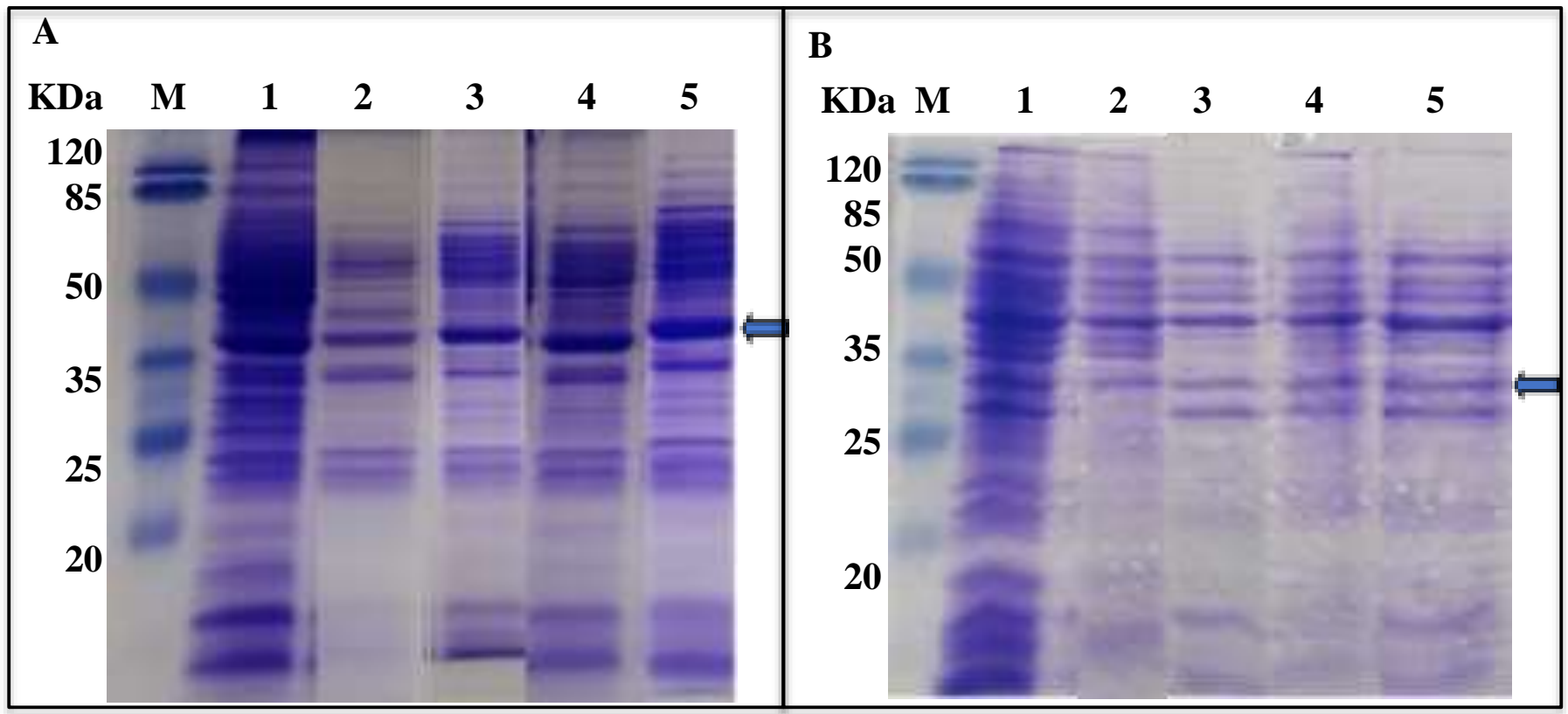

Figure 4. SDS-PAGE analysis of lipase isolates from Geobacillus stearothermophillus (A) and Anoxybacillus flavithermus (B), both gels stained with Coomassie blue. $\mathbf{M}$ is molecular weight markers. Lanes $1 \mathbf{A} \& \mathbf{B}$. Crude lysate, 2A. Heat treatment at $70^{\circ} \mathrm{C}$ supernatant, 2B. Heat treatment at $55^{\circ} \mathrm{C}$ supernatant, $3 \mathrm{~A}$. Ethanol precipitate at $80 \%$, 3B. Ethanol precipitate at $60 \%$, 4A. Ammonium sulfate precipitate at $95 \%$, 4B. Ammonium sulfate precipitate at $80 \%, 5$ A \& B. Gel filtration fraction. Arrows indicate the lipase bands from Geobacillus stearothermophillus and Anoxybacillus flavithermus samples with molecular weights of $42 \mathrm{kDa}$ and $33 \mathrm{kDa}$ respectively.

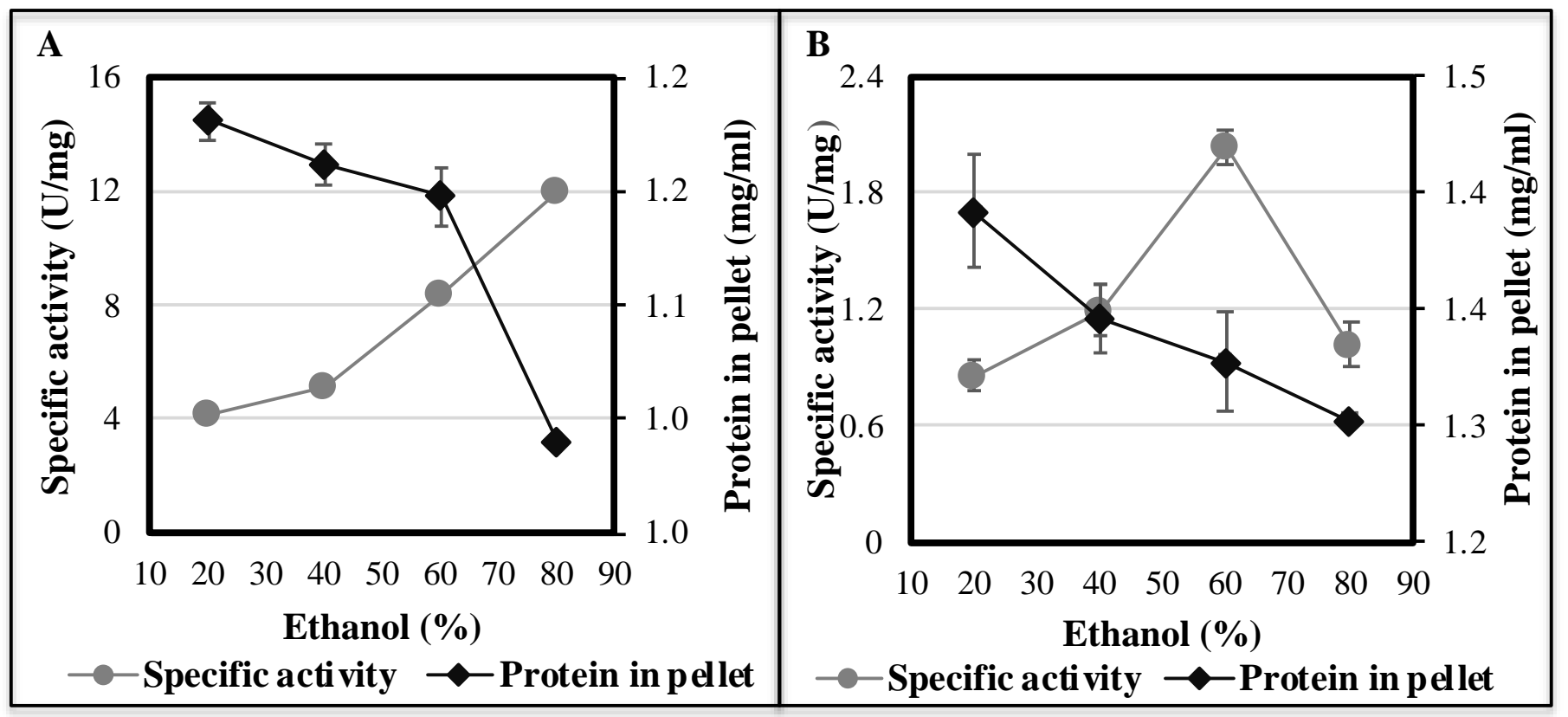

Figure 5. Lipase activity and protein concentration in pellets of cell lysates from Geobacillus stearothermophilus (A) and Anoxybacillus flavithermus (B) after ethanol precipitation. Error bars represent the standard deviation. 


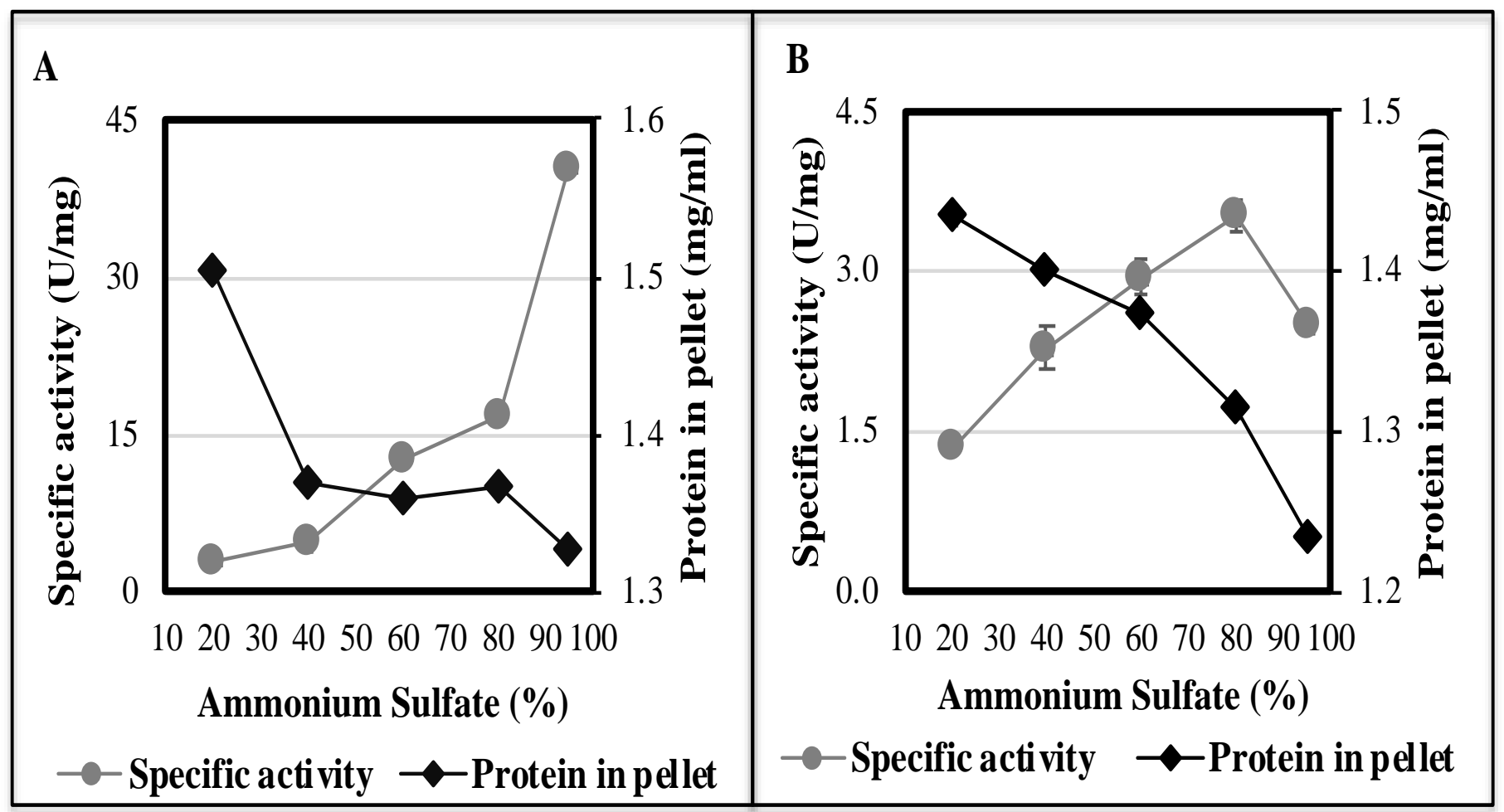

Figure 6. Lipase activity and protein concentration in pellets after dialysis of cell lysates from Geobacillus stearothermophilus (A) and Anoxybacillus flavithermus (B) after ammonium sulfate precipitation. Error bars represent the standard deviation.

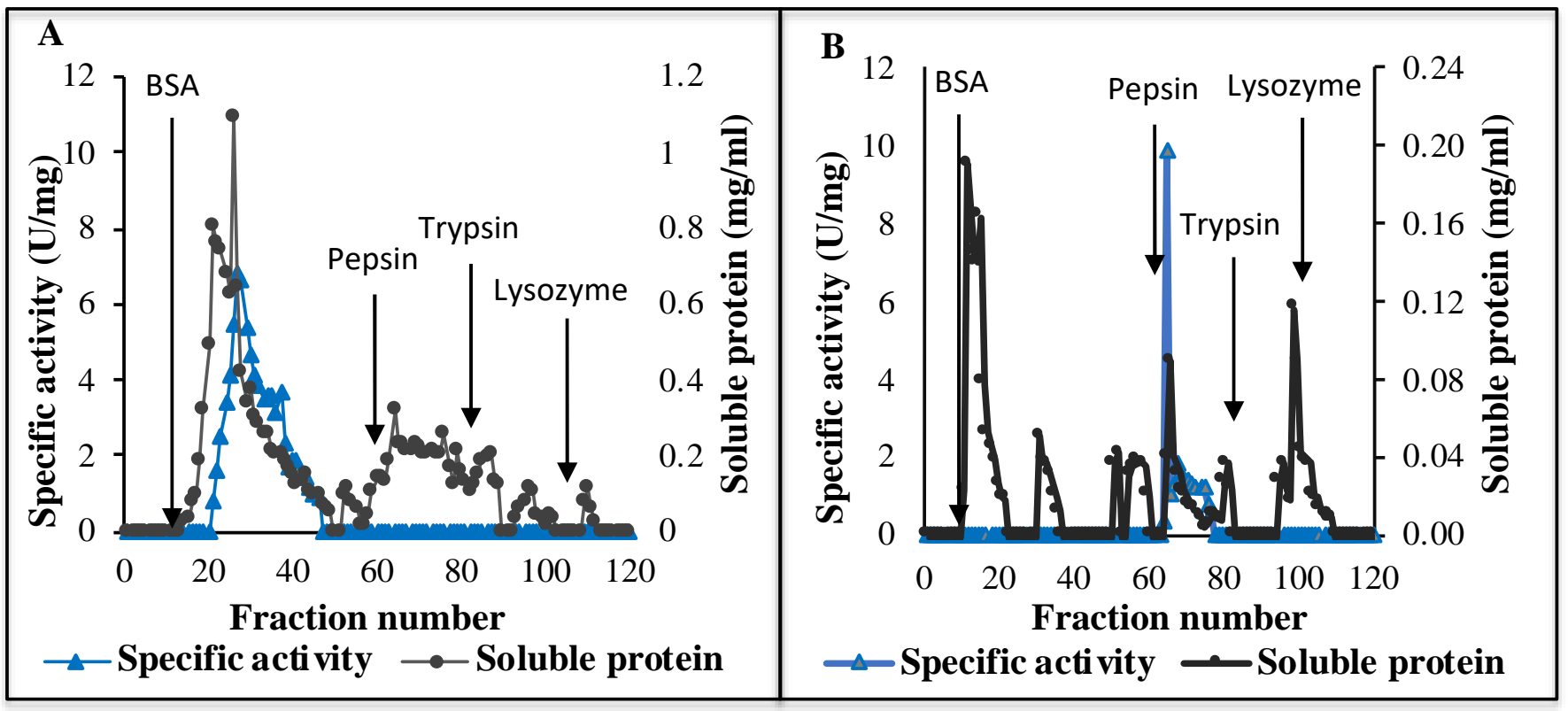

Figure 7. Size-exclusion chromatography on Sephadex G-100. Specific lipase activity and soluble protein from cell lysates from Geobacillus stearothermophilus (A) and Anoxybacillus flavithermus (B) were loaded on a Sephadex G-100 column $(36.0 \mathrm{~cm} \times 2 \mathrm{~cm}$ ) equilibrated in Tris HCL buffer $(\mathrm{pH} 7.5)$. The flow rate was $0.5 \mathrm{ml} / \mathrm{min}$, and the chromatography was carried out at $4^{\circ} \mathrm{C}$. Molecular weight protein standards were used to calibrate the column and calculate the lipases molecular weights based on retention times.

Funding: This research received no external funding

Acknowledgments: This work was carried out with the financial support from the Utah State University Agriculture Experiment Station, Utah State University (Logan, UT 84322-4810) and approved as paper number 9225.

Conflicts of Interest: The authors declare no conflict of interest 


\section{REFERENCE}

1. Louwrier A. Industrial products-the return to carbohydrate-based industries. Biotechnol Appl Biochem. 2013;27(1):18.

2. Bornscheuer UT. Microbial carboxyl esterases: classification, properties and application in biocatalysis. FEMS Microbiol Rev. 2002;26(1):73-81.

4. Hasan F, Shah AA, Hameed A. Industrial applications of microbial lipases. Enzyme Microb Technol. 2006;39(2):235251.

5. Aloulou A, Puccinelli D, De Caro A, Leblond $Y$, Carrière $F$. A comparative study on two fungal lipases from Thermomyces lanuginosus and Yarrowia lipolytica shows the combined effects of detergents and $\mathrm{pH}$ on lipase adsorption and activity. Biochim Biophys Acta. 2007; 1771(12):1446-56.

6. Houde A, Kademi A, Leblanc D. Lipases and their industrial applications. Appl Biochem Biotechnol. 2004;118(13):155-70.

7. Sharma R, Chisti Y, Banerjee UC. Production, purification, characterization, and applications of lipases. Biotechnol Adv. 2001;19(8):627-62.

8. Cardenas F, Alvarez E, de Castro-Alvarez MS, Sanchez-Montero JM, Valmaseda M, Elson SW, et al. Screening and catalytic activity in organic synthesis of novel fungal and yeast lipases. J Mol Catal B Enzym. 2001;14(4-6):11123.

9. Li H, Zhang X. Characterization of thermostable lipase from thermophilic Geobacillus sp. TW1. Protein Expr Purif. 2005;42(1):153-9.

10. Becker P, Abu-Reesh I, Markossian S, Antranikian G, Märkl H. Determination of the kinetic parameters during continuous cultivation of the lipase-producing thermophile Bacillus sp. IHI-91 on olive oil. Appl Microbiol Biotechnol. 1997;48(2):184-90.

11. Bakir ZB, Metin K. Purification and characterization of an alkali-thermostable lipase from thermophilic Anoxybacillus flavithermus HBB 134. J Microbiol Biotechnol. 2016;26(6):1087-97

12. Ekinci AP, Dinçer B, Baltaş BN, Adıgüzel A. Partial purification and characterization of lipase from Geobacillus stearothermophilus AH22. J Enzyme Inhib Med Chem. 2016;31(2):325-31.

13. Beatty NF, Walsh MK. Influence of thermosonication on Geobacillus stearothermophilus inactivation in skim milk. Int Dairy J. 2016;61:10-7.

14. Saw JH, Mountain BW, Feng L, Omelchenko MV, Hou S, Saito JA, et al. Encapsulated in silica: genome, proteome and physiology of the thermophilic bacterium Anoxybacillus flavithermus WK1. Genome Biol. 2008;9(11):R161.

15. Glogauer A, Martini VP, Faoro H, Couto GH, Müller-Santos M, R. Monteiro RA, et al. Identification and characterization of a new true lipase isolated through metagenomic approach. Microb Cell Fact. 2011;10(1):54.

16. Nam SH, Walsh MK, Yang KY. Comparison of four purification methods to purify cysteine protease from Asian pear fruit (Pyrus pyrifolia). Biocatal Agric Biotechnol. 2016;5:86-93.

17. Kwon MA, Kim HS, Hahm DH, Song JK. Synthesis activity-based zymography for detection of lipases and esterases. Biotechnol Lett. 2011;33(4):741-6.

18. Singh R, Gupta N, Goswami VK, Gupta R. A simple activity staining protocol for lipases and esterases. Appl Microbiol Biotechnol. 2006;70(6):679-82.

19. Wilkesman J, Hernández Z, Fernández M, Contreras LM, and L. Kurz L. Enhancement of sequential zymography technique for the detection of thermophilic lipases and proteases. Amino Acids. 2014;46(5):1409-13.

20. Choi NS, Choi JH, Kim BH, Han YJ, Kim JS, Lee SG, et al. Mixed-substrate (glycerol tributyrate and fibrin) zymography for simultaneous detection of lipolytic and proteolytic enzymes on a single gel. Electrophoresis 2009;30(12):2234-7.

21. Lee DW, Kim HW, Lee KW, Kim BC, Choe EA, Lee HS, et al. Purification and characterization of two distinct thermostable lipases from the gram-positive thermophilic bacterium Bacillus thermoleovorans ID-1. Enzyme Microb Technol. 2001;29(6-7):363-71.

22. Balan A, Ibrahim D, Abdul Rahim R, Rashid A, Azzahra F. Purification and characterization of a thermostable lipase from Geobacillus thermodenitrificans IBRL-nra. Enzyme Res. 2012;987523.

23. Ebrahimpour A, Rahman RNARA, Basri M, Salleh AB. High level expression and characterization of a novel thermostable, organic solvent tolerant, 1, 3-regioselective lipase from Geobacillus sp. strain ARM. Bioresour Technol. 2011;102(13):6972-81.

24. Sarkar $P$, Lepcha K, Ghosh S. Purification and characterization of solvent stable lipase from a solvent tolerant strain of Geobacillus stearothermophilus PS 11. J Microbiol Biotechnol Food Sci. 2016;5(6):602-5. 
25. Petersen El, Valinger G, Sölkner B, Stubenrauch G, Schwab H. A novel esterase from Burkholderia gladioli which shows high deacetylation activity on cephalosporins is related to $\beta$-lactamases and DD-peptidases. J Biotechnol. 2001;89(1):11-25.

26. Castro-Ochoa LD, Rodríguez-Gómez C, Valerio-Alfaro G, Ros RO. Screening, purification and characterization of the thermoalkalophilic lipase produced by Bacillus thermoleovorans CCR11. Enzyme Microb Technol. 2005;37(6):648-54.

27. Giver L, Gershenson A, Freskgard PO, Arnold FH. Directed evolution of a thermostable esterase. Proc Natl Acad Sci USA. 1998;95(22):12809-13.

28. Manco G, Adinolfi E, Pisani FM, Ottlina G, Carrea G, Rossi M. Overexpression and properties of a new thermophilic and thermostable esterase from Bacillus acidocaldarius with sequence similarity to hormone-sensitive lipase subfamily. Biochem J. 1998;332(1):203-12.

29. Tayyab M, Rashid N, Akhtar M. Isolation and identification of lipase producing thermophilic Geobacillus sp. SBS4S: cloning and characterization of the lipase. J Biosci Bioeng. 2011;111(3):272-8.

30. Jiang $Y$, Zhou X, Chen Z. Cloning, expression, and biochemical characterization of a thermostable lipase from Geobacillus stearothermophilus JC. World J Microbiol Biotechnol. 2010;26(4):747-51.

31. Ay F, Karaoglu H, Inan K, S. Canakci S, Belduz AO. Cloning, purification and characterization of a thermostable carboxylesterase from Anoxybacillus sp. PDF1. Protein Expr Purif. 2011;80(1):74-9.

32. Eminoğlu A, Ülker S, Sandalli C. Cloning, Purification and Characterization of acetyl xylane esterase from Anoxybacillus flavithermus DSM 2641 T with activity on low molecular-weight acetates. Protein J. 2015;34(4):23742.

33. Horchani H, Mosbah H, Salem NB, Gargouri Y, Sayari A. Biochemical and molecular characterisation of a thermoactive, alkaline and detergent-stable lipase from a newly isolated Staphylococcus aureus strain. J Mol Catal B Enzym. 2009; 56(4):237-45.

(C) 2021 by the authors. Submitted for possible open access publication under the terms and conditions of the Creative Commons Attribution (CC BY NC) license (https://creativecommons.org/licenses/by-nc/4.0/). 